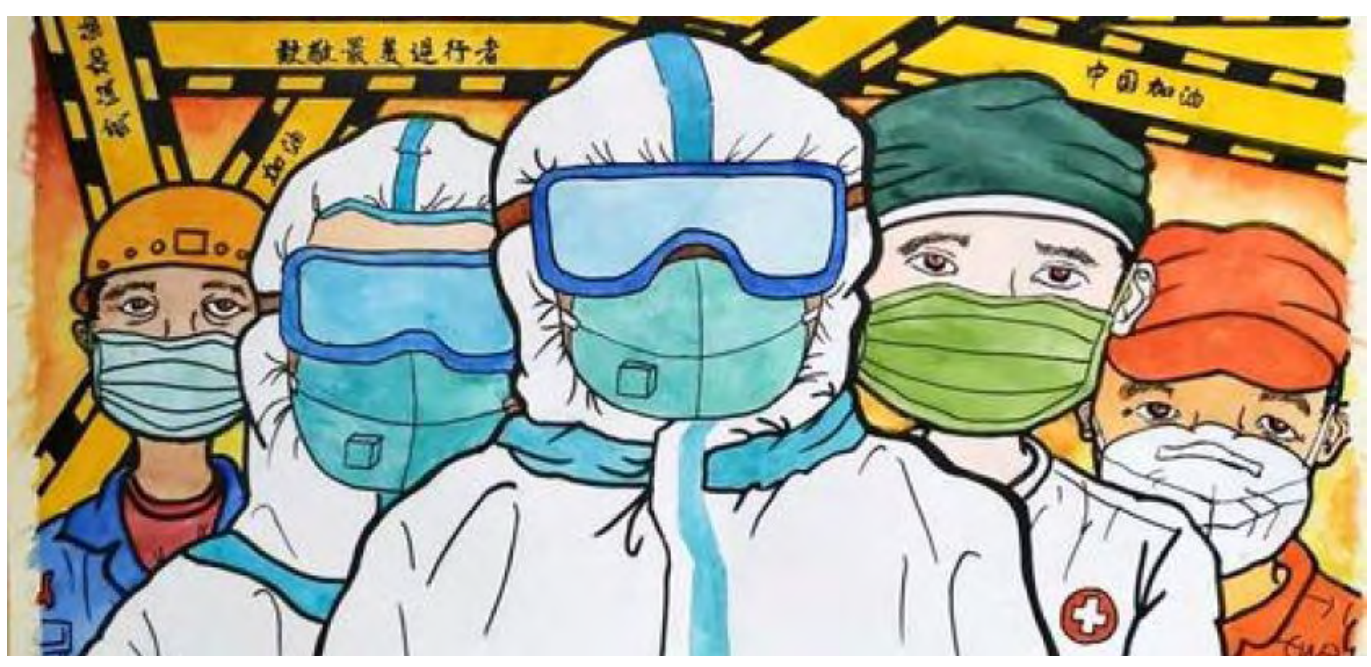

\section{The Cultural}

Politics of

\section{National}

Tragedies and

\section{Personal Sacrifice}

\author{
State Narratives of China's \\ 'Ordinary Heroes' of the \\ COVID-19 Pandemic
}

Kailing XIE

Yunyun ZHOU

How did China transform its initial 'Chernobyl' moment triggered by the COVID-19 outbreak into a story of national celebration? Since the end of February 2020, state-orchestrated narratives that consolidate the CCP's national saviour image and citizens' patriotic sentiment have become a dominant theme in China's mass media. Through an analysis of a state-sponsored $T V$ series, this essay argues that a new humanistic approach is being used by the Party-State for emotional mobilisation of the public to support its leadership in times of crises.
PC: Heroes in Harm's Way, Guangzhou Vocational High School of Trade, Year 2018 Class 3, Ye Zhihong.
W hile the rest of the world is still battling the latest wave of COVID-19 and implementing lockdown measures to combat the spread of the virus, China has been celebrating its 'victory' over the pandemic since the end of February 2020, with Xinhua (2020) announcing a book praising the country's success in disease control to be published in six languages. Compared with the initial crisis being described as China's 'Chernobyl moment' (Shih 2020), at a time when criticism from ordinary citizens abounded, the current discursive space in China appears to be 
largely celebratory of the centrally coordinated state efforts that led to victory in China's so-called war against COVID-19. Zhang (2020) uses the concept of 'disaster nationalism' to describe the use of this particular mode of messaging and emotional mobilisation during times of crisis, which promotes narratives that highlight the heroic sacrifices of individuals and the unity of the nation.

COVID-themed news reports, award ceremonies, documentaries, and TV series singing the praises of 'everyday heroes' in controlling the virus have become a daily occurrence in the Chinese media. In these state-orchestrated narratives of victory, two dimensions are particularly highlighted: the superiority of socialism with Chinese characteristics under the leadership of the Chinese Communisty Party (CCP), and ordinary Chinese citizens' willing participation through voluntarism to cooperate with the state's leadership. These dual forms of praise juxtapose individual citizens and the Party-State in highlighting the dialectical unity that characterises the contemporary Chinese nation. In particular, several state-sponsored TV series based on real stories of ordinary people during the Wuhan lockdown aired both nationally and internationally in 2020. This essay focuses on one of these high-profile state-sponsored TV series, the controversial Heroes in Harm's Way (最美逆行 者), which has been hailed as the first drama of its kind (CCTV News 2020). Through an analysis of this TV series, this essay investigates the primary narrative employed: the sentimental depiction of a national tragedy and the construction of 'ordinary heroes'.

Our analysis of the latest strategies in the state narrative following the COVID-19 pandemic is built on the continuing scholarly discussion of China's 'emotion work', which has long been part of the CCP's conscious strategy of psychological engineering for the purpose of political mobilisation (Perry 2002). In the reform era, despite the shift from socialist revolution to economic development, emotion-laden mobilisation strategies continue to appear in the CCP's state discourses and media representations. Carefully orchestrated emotional performances led by the Propaganda Department range from community theatre to messaging through modern-day communications technology, including TV and cinema, which responds to and incorporates public sentiment (Perry 2013). Our analysis reveals that the Chinese Party-State's 'emotion work' has taken on new forms to adapt to the competition and shifting demands brought by market reforms. These new types of 'emotion work' adopt a humanistic approach in that personal desires and efforts gradually take on a central role in strengthening and authenticating state ideology (Dai 2018). Consequently, the glorification of 'sacrificial' and 'grateful' citizens to these stories tantalises human desires to encourage citizens' willing compliance with the Party-State's transformation of a national tragedy into its narrative of victory.

\section{Retelling 'National Tragedies'}

China's Leninist Party-State perceives control over national discourse as being key to its political longevity. Through its dynamic propaganda apparatus, CCP discourse permeates, conditions, and filters every aspect of Chinese politics, especially following the occurrence of critical events (Xie forthcoming). Sorace's (2017) seminal work on the Party-State's post-disaster responses to the Wenchuan earthquake, which killed more than 85,000 people on 12 May 2008, provides a useful example to illustrate some key features of the Party-State's narrative control that continue to be used today. Although the Chinese Government was praised for its rapid response to the emergency and for granting media access to the disaster site immediately after the earthquake, Sorace noted a change in public opinion after the publication of reports about the collapse of shoddily constructed schools that resulted in the deaths of at least 5,000 schoolchildren.

To handle the aftermath of the disaster, the Party-State relied on the 'body politics' of its cadres, who supposedly embody the Party's spirit (党性) through their personal sacrifice and suffering, showing the Party's benevolence to the people to legitimise its rule (Sorace 2017: 40). The theme of the self-sacrifice of Party cadres is often reflected 
in the exemplary stories in which they prioritise the Party's mission above any personal considerations, including their own health and family interests. This theme is evident in almost all the episodes of the COVID-19 drama we are analysingsometimes subtly through background imagery such as the use of Party flags or badge-wearing doctors and nurses, and other times more explicitly articulated, such as through the assertion that 'Party cadres should volunteer first' made during a meeting with a local Party branch in the first episode (Image 1). Expressions of the Party's leadership role are loud and clear in each episode, be it through the authoritative voices of CCTV News broadcasting the national deployment of resources in supporting Wuhan, or the parade of trucks and buses shipping supplies into the city. Through various displays of the Party's omnipresence in leading disaster-relief works, the Party-State is rendered as the source of meaning and moral guidance for Chinese society, as well as the source of happiness and life itself. The message remains clear: the CCP's leadership is what assures such a Chinese victory.

Although the current narrative continues to highlight cadres' willingness to sacrifice their own needs and families' interests to serve the Party's purposes, it has added strategic displays of cadres' intimate family lives in these stories to emphasise their humanness. For example, in episode one, when a military doctor is tasked with supporting

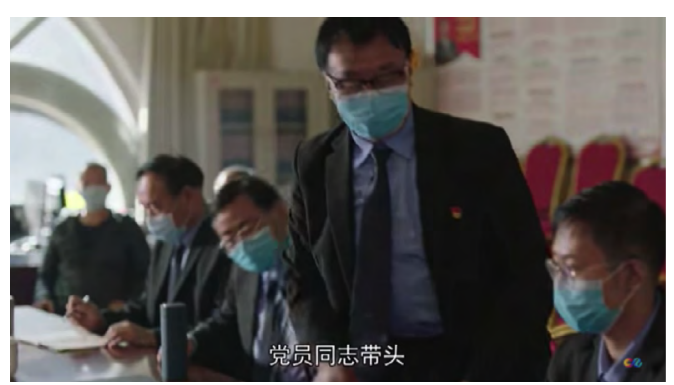

Image 1: A mobilisation meeting initiated by the party branch in the local bus company, where party members are called on to take the lead in volunteering to support. Heroes in Harm's Way. episode 1. hospitals in Wuhan, she goes home to explain the situation to her daughter and ageing parents (Image 2). Although her father has just had major surgery, he supports her work. She sits down with her crying daughter, saying it is her duty as a soldier and a doctor to defend the country and save lives. This is a subtle departure from the previous portrayals of the Party cadre as almost superhuman, with their human fragility veiled until martyrdom. Portraying cadres through the lens of worried parents and crying children while they fully commit to the Party mission casts the Party's image with relatable human faces. In our view, such tactical displays of cadres' humanity feed into the growing appetite among Chinese audiences for emotional authenticity in the media content they consume, to enhance the 'emotional stickiness' of the Party discourse.

In addition, Sorace (2017) elucidates the discursive logic that binds the sacrifice of the Party cadre with the debt of gratitude incurred by the people. He contends that the Gratitude Education Campaign (感恩教育运动) launched after the Wenchuan earthquake-a top-down movement aimed at fostering a culture of gratitude towards the Party to remove negative feelings among those affected by the disaster-presents the 'modular blueprint of Party legitimacy' (Sorace 2017: 41). Similar emphasis on gratitude towards the Party's leadership is noted in the current COVID-19 crisis, but with a more subtle and

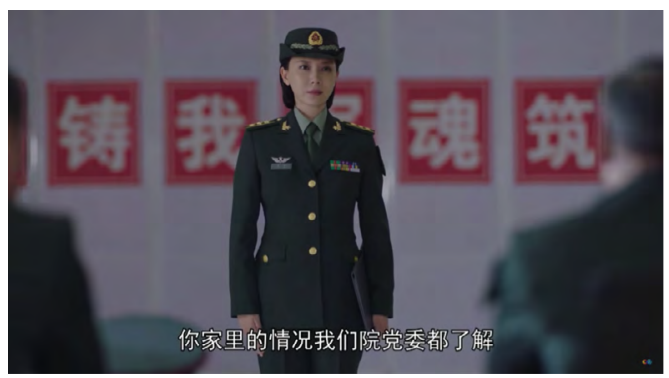

Image 2: Military doctor Xiaoning volunteers herself at the Party branch meeting to support Wuhan, despite her family difficulties (ailing parents caring for her young daughter, and her husband serving long-term abroad). Heroes in Harm's Way, episode 1. 
diverse approach adapting to the changing public mood. For example, the suggestion of launching another gratitude education campaign among Wuhan residents to thank the Party for its leadership-made by the Party secretary in Wuhan on 7 March 2020-was met with public outrage. Three days later, the official message swiftly changed to 'the Party and Chinese people thank the people of Wuhan', as publicised in a speech given by President Xi Jinping in which he praised the people of Wuhan for their 'Chinese spirit, Chinese strength and ... family/national sentiment' (Xinhua 2020). Alongside Party cadres, ordinary citizens, frontline workers, and volunteers have become the common targets of this new gratitude campaign, evidenced in the TV series in which gratitude is mutually expressed among people and the Party. Notably, the drama also features an intense encounter between a Wenchuan earthquake survivor and a People's Liberation Army soldier who took part in the earthquake rescue, with the earthquake survivor now the medical worker who vows to sacrifice everything to help the soldier, who is a COVID patient in a Wuhan hospital. Such scenes enhance the show's emotional appeal through a heightened sense of paying back the previous gratitude received. This sense of paying back can also be found in the volunteer bus driver, a rural migrant woman, who in the first episode explains her heroism as a way of 'paying back to her beloved Wuhan, where she lived for 15 years'.

The discursive strategy of gratitude manufactures intimacy between the Party and the people to further blur the boundaries between the Party, the people, and the Chinese nation, rendering them as indivisible. The multilayered expressions of gratitude within the country serve to harmonise social tensions exacerbated during COVID-19 and present the CCP as the only legitimate national unifying force. They also consolidate the political leadership of the Party by documenting the moral debts of the people under its monopoly, implying the imperative of future payment. This series reminds people of both the formidable strength and the compassion of the Party as a benevolent ruler, on which the survival and prosperity of the Chinese people supposedly depend. Yet, Sorace (2020) incisively points out that gratitude, seen in both US and Chinese political discourse in the midst of the pandemic, is the ideology of sovereignty in crisis.

\section{Narrating ‘Ordinary Heroes'}

Another dimension of China's new humanistic state narrative is to put human desires and sacrifices at the centre of its portrayal of ordinary people and their struggles with the health crisis that suddenly upended their daily routines, their workplaces, and their communities. Against the background narratives of COVID-19 as a national tragedy, this TV series embraces the new human-centred emotional mobilisation approach by highlighting citizens' struggles to fulfil their fundamental human desires. It constructs a powerful and mobilising narrative that ordinary citizens have become China's 'counter-pandemic heroes' with an extraordinary sense of self-sacrifice and endurance, regardless of their professional and social roles.

One of the centrepieces of Xi Jinping's ideological campaign is the 'Construction of Family Values' (家风建设), which considers harmonious and virtuous families as the cornerstone of a prosperous and powerful Chinese nation. It is, therefore, not surprising that this state-produced series centres its narrative on the lived and resolved struggles of idealised heterosexual and 'productive' families. All seven stories presented in the series highlight the characters' desires for a heteronormative family life, with couples longing to see each other, and parents missing their young children. This is a theme particularly emphasised in episodes five and six, in which a four-member family is forced to separate when a young woman and her mother-in-law start to show COVID-19 symptoms and her husband has to move to another place with their young son.

The story unfolds as the mother-in-law becomes increasingly angry and frustrated by the fact that she could not stay with her son and grandson even on the eve of Chinese New Year. In the meantime, the young woman, despite her own illness, has to make sure the rules of self-quarantine are strictly followed in their apartment and take care of her 
uncooperative mother-in-law. In the telling of the story of a family hit hard by the pandemic, the mother-in-law's outspoken anger, distrust, and complaints contrast with the young woman's calm reactions and underlying anxiety, which employ the difficult mother-in-law stereotype that invites strong emotional empathy from the audience with an everyday domestic scenario. The depiction of these relatable human emotions reinforces the series' portrayal of the COVID-19 pandemic as an unpredictable and unmanageable event that tears apart families and distances parents from their children, and husbands from wives. Yet, exemplified by the selfless devotion of the daughter-in-law in the series, the new state narrative emphasises that families should serve as a buffer zone where the anxiety, anger, and distress caused by a national crisis should be digested internally to produce a harmonised and united front in the battle against COVID-19.

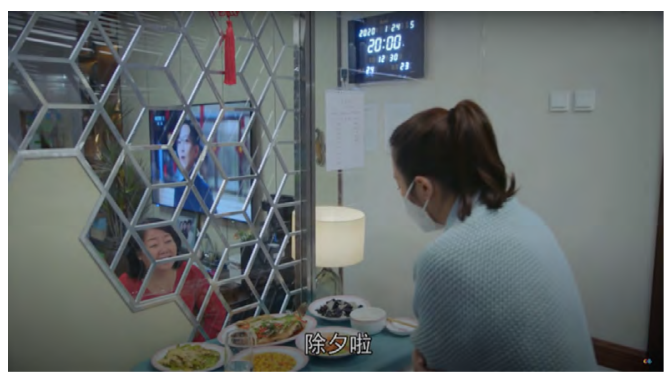

Image 3: New Year's Eve in home quarantine. A young woman and her mother-in-law, who have no choice but to share their festival feast separated by a glass shield. Heroes in Harm's Way, episode 6.

The narrative skilfully interweaves these heartwrenching and distressing experiences that are relatable for every ordinary citizen struggling with the tragedy of the pandemic. Bridging individual experiences with the national situation is a key narrative strategy developed in this latest state-sponsored cultural production and it serves a double purpose. First, by connecting the fates of individuals, families, and the nation, it creates a collective sympathy that makes sense of, and reconciles, the anger and distress that were felt at the beginning of the epidemic in Wuhan and elsewhere in China. At the same time, it provides an incentive for the audience to glorify those who have lived through the pandemic as 'ordinary heroes' and the 'sacrifices' they have had to make. Both in this series and in other state media coverage, Wuhan, as the original epicentre of the coronavirus, has been repetitively glorified as a 'heroic city' (英雄的城市) where the citizens meticulously followed the lockdown policy with 'a strong sense of responsibility and spirit of self-sacrifice’ (People's Daily 2020).

To solidify such heroism-unlike the CCP's previous propaganda style, which glorified an impersonal devotion to the Party order-this series praises the self-motivated volunteerism and professional dedication that are portrayed from an individualistic perspective. These portrayals often tactically sugarcoat patriotism and sacrifice with a heartfelt sense of self-realisation. To enhance its credibility and render the portrayals more realistic and representative, this series depicts a variety of professions, including military medical units, doctors and nurses, drivers, construction workers, grassroots social workers, and cleaners. Most of these professions indeed played crucial roles in maintaining Wuhan as a functional city during its 76 days of lockdown. Yet almost all the protagonists in the show demonstrate an eagerness to do well in their jobs or volunteer activities, to prove they are useful in such a national crisis. This is exemplified by the young male musician who delivers free meals to hospitals 24 hours a day to express his gratitude for the healthcare workers in Wuhan who worked hard to save his grandmother's life.

What this series chooses not to show, however, is that many of the sacrifices that took place in Wuhan were neither voluntary nor intended to 'save the nation', and those who courageously stood up to speak the truth about the pandemic were initially oppressed. For instance, Dr Li Wenliang, one of China's first whistle-blowers, who was reprimanded by the state for 'spreading rumours', died on 7 February 2020 from COVID-19. His death sparked huge waves of anger among Chinese citizens and demands for more transparency and freedom of speech. The popular sentiment at that time led to the Party-State joining the public in an attempt to appear to be 'on the 
side of the people', mourning for the doctor, and later recognising him as a martyr, together with 13 others, in April 2020. Since it is impossible to completely eliminate these collective memories, Beijing has apparently chosen to integrate these stories of martyrdom into the new narrative of 'ordinary heroes', which transforms social grievances into a unifying sentiment of nationalistic pride. This new humanistic approach is not only meant to silence and harmonise public reflections on the questionable political transparency and brutality of the state-enforced lockdown during the pandemic, but also aims to regain the trust of ordinary Chinese citizens in the Party-State.

\section{Recasting a Humanised Party}

This essay has analysed the new humanistic approach adopted by China's state media to rewrite its history of the COVID-19 pandemic. Based on a case study of the first state-sponsored media representations of ordinary heroes in the epicentre of the crisis, Wuhan, it is clear that the Chinese Party-State has readily adopted narratives of disaster nationalism, gratitude politics, and heteronormative human desires as a means of nationalising personal lives to serve its political agenda. Compared with the Maoist emotional rituals that directly emphasised the collective good and state-defined goals, this new humanistic approach has evidently been designed to appeal to China's new generation of cultural consumers who value and actively seek sensational, individualistic, and relatable cultural experiences based on human feelings, desires, and struggles (Dai 2018). We argue that this humanistic and desire-centred approach has made the state media a powerful narrative tool to fuse together the Party-State's grand national, societal, and governing goals with the everyday life aspirations of China's 1.4 billion citizens.

However, these narrative strategies deployed in the first state-produced TV series focusing on the national pandemic response are still just an emerging tactic and have not yet proved to be fully accepted by the audience. While Heroes in Harm's Way has become one of the most well-known and widely discussed TV series of the year, its rating on popular online forums such Douban and Zhihu reached such lows that these platforms eventually turned off the public rating and comment function for the show. Despite the series' attempt to create relatable and realistic COVID-19 stories, the Chinese public still found it inauthentic and overly ideological. One strong public criticism of this series was related to its 'backward gender values' and its unfair portrayal of women and their contribution to the fight against the pandemic (Wang 2020). As demonstrated by these public criticisms, we argue that the attempt to coopt these highly politicised emotions and narratives to channel them through a market-oriented content strategy also creates unprecedented challenges for China's authoritarian state media. The debates over, and reception of, the series should be seen as not merely signs of disaffection towards a TV program that failed to entertain, but important markers that reveal the latent civic consciousness alive within Chinese society, which is actively resisting the state's rewriting of public memory and the human tragedies experienced during the COVID-19 crisis.

Both authors contributed equally to this article. 
This text is taken from Made in China Journal: Volume 6, Issue 1, 2021, edited by Ivan Franceschini and Nicholas Loubere, published 2021 by ANU Press, The Australian National University, Canberra, Australia.

$$
\text { doi.org/10.22459/MIC.06.01.2021.02 }
$$

